\title{
IPTEK BAGI MASYARAKAT KELOMPOK PANDE BESI TARIK SIDOARJO
}

\author{
Adi Sucipto $^{1)}$, Budijanto ${ }^{2)}$, Nur Iffah ${ }^{3)}$ \\ IKIP Budi Utomo Malang, Jalan Simpang Arjuno 14B Malang \\ 1) email: adis123.com@gmail.com, \\ 2) email: budijanto@yahoo.com, \\ 3) email: nur_iffah@yahoo.com
}

\begin{abstract}
Tarik Krian Sidoarjo is one of the areas of agricultural technology and the result pemroduk carpentry most reliable and most turnover compared with other regions. Products produced are tools such as the hoe, trowel, sickles, shovels, machetes, bendo and others. However, these efforts have not seen a sign - a sign of progress and development, which means, it is necessary to increase output menajamen improvement.The method used was a demonstration and practice. Demonstrations conducted at the stage of the introduction of tools to etalworkers, while the practice is performed immediately after the target is considered to use a tool that is prepared to increase production.Activity Results: Effectiveness and efficiency of technology tools / lathe versatile mechanical system seen from the large expenses associated with the manufacture of the benefits calculated by financially. (1) Changes in the behavior of workers before and after using the technology tools / lathe versatile mechanical system. (2) The increase in family income before and after using the technology.
\end{abstract}

Keywords: Agricultural technology, rowel, sickles, shovels.

\section{PENDAHULUAN}

Krian, Sidoarjo adalah salah satu wilayah yang berpotensi dalam dunia perdagangan dan perindustrian. Di wilayah ini tumbuh beberapa pengrajin logam dan permesinan. Wilayah Krian merupakan salah satu pemroduk hasil teknologi pertanian dan pertukangan paling handal dan paling besar omsetnya dibanding dengan wilayah lain. Produk yang dihasilkan adalah alat-alat seperti cangkul, cetok, arit, sekop, parang, bendo dan lain-lainnya. Namun demikian usaha ini belum terlihat tanda - tanda adanya kemajuan dan perkembangan yang berarti, apabila ditinjau untuk kepentingan yang lebih luas lagi seperti misalnya untuk pasar antar pulau.

Dari hasil survey di lapangan ditengarai bahwa faktor utama penyebab terjadinya penurunan produktivitas kerajinan logam adalah, dikarenakan teknologi produksi yang digunakan untuk memproses alat-alat pertanian dan pertukangan masih sederhana, sehingga produktivitasnya masih terbatas. Dengan kondisi seperti itu, menyebabkan tidak bisa memproduksi alat-alat pertanian dan pertukangan secara besar-besaran atau mutu alat-alat tersebut kurang baik. Dengan argumentasi tersebut, maka perlu dibuatkan alat-alat teknologi proses produksi yang lebih memadai. Peralatan pendukung ini berupa alat finishing/pengasah ujung arit, cetok, bendo dan lainnya, alat pemotong pemegang arit, cetok, bendo dan lainnya, dan alat bubut kayu. Yang lebih dkenal alat atau mesin serba guna. Dengan kegiatan ini diharapkan permasalahan pokok pada pengrajin logam ini dapat diatasi.

Alat/mesin bubut serba guna yang ada dipasaran ada bermacam-macam jenisnya. Model lama biasa dengan menggunakan tenaga manusia atau manual. Alat ini kemampuannya sangat terbatas, karena tidak bisa bekerja secara cepat dan tepat, serta tidak bisa menghasilkan mutu logam yang lebih 
baik. Sedang dengan alat/mesin bubut serba guna sistem mekanik kemampuannya sangat baik, karena alat ini dapat menghasilkan logam menjadi lebih rapi, dapat memotong dan membubut kayu /gagang pemegang catok, sabit, dan lainnya lebih bagus dan kokoh, bekerja sangat cepat, serempak dan non stop, serta dapat mengahasilkan alat-alat pertanian dan pertukangan mutunya lebih baik. Selain itu dalam membuat alat-alat pertukangan dan pertanian dibutuhkan pula alat finishing gerinda dan bubut tangkai sabit dan cetok. Tenaga utamanya/ energinya dapat diambil dari arus listrik maupun dari motor bensin/ diesel. Alat ini sangat praktis penggunaanya, mudah perawatan dan memperbaikinya, serta sangat tangguh terhadap gangguan dari luar.

Karena begitu besar daya kemampuannya, maka alat ini banyak diminati oleh beberapa para pengrajin logam. Dari salah satu pengrajin logam yang pernah menggunakan alat ini ternyata dapat membawa manfaat yang sangat besar bagi pengrajin tersebut. Hasil yang paling nampak dirasakan adalah jumlah pesanan semakin bertambah banyak yang datang dari perbagai fihak dan penjuru kota.

Seperti pengrajin logam lainnya, di wilayah Krian Sidoarjo ini tumbuh beberapa pengrajin logam yang begitu semarak, termasuk salah satunya adalah usaha logam yang menjadi mitra kerja program Vucer ini, yang dipimpin oleh salah seorang yang sudah berpengalaman dalam bidang kerajinan logam. Usaha ini sudah dirintis selama kurang lebih 12 tahun. Tenaga kerja yang membantu usaha logam saat itu ada 4 orang. Usahanya mengalami kemajuan setelah menggunakan alat/ bubut serbaguna sistem mekanik, sehingga omsetnya bertambah banyak dan berkembang secara signifikan.

Pada umumnya manajemen yang diterapkan pada usaha kecil ini masih menggunakan manajemen keluarga.
Segala kegiatan masih dikendalikan oleh pemilik dan keluarganya. Di bidang administrasi misalnya pembukuan, keuangan, personalia, dan pemasaran semuanya dilakukan dengan cara konvensional.

Kondisi produksi selama ini masih mengandalkan teknologi sederhana yang kemampuan produksinya juga terbatas. Dengan menggunakan teknologi seperti ini, usaha ini belum bisa dikatakan lebih maju dan belum ada perkembangan yang berarti. Apabila peralatan produksi telah dapat dimiliki, maka dengan rasa yakin penuh optimis produktivitas akan meningkat secara signifikan. Hal ini sudah terlihat ada tanda - tanda para langganan merasa puas karena pesanannya dapat lebih cepat dan mutunya lebih baik dibandingkan dengan sebelum menggunakan alat yang baru.

Jangkauan pemasaran tidak saja terbatas pada langganan tetap, tetapi sudah menjalin dengan beberapa instansi seperti deperindag dan departemen pertanian. Kualitas tenaga kerja yang mengerjakan pembuatan alat-alat pertanian dan pertukangan ini sudah berpengalaman beberapa tahun walaupun sekolah mereka hanya SLTP dan tidak tamat SLTA. Hal yang belum disentuh oleh pengrajin logam yaitu cara mengelola usahanya belum sungguhsungguh dan belum profesional, sehingga usahanya mengalami pasang surut. Alasan lain karena pengrajin logam ini memang belum memiliki kemampuan dan pengetahuan bagaimana berwirausaha yang baik. Dampak langsung yang dapat dirasakan oleh pengrajin adalah bertambahnya tenaga kerja, bertambahnya keuntungan dan kesejahteraan meningkat baik pengrajin dan warga sekitarnya dengan semakin ramainya usaha logam ini.

Dampak yang diperoleh dari kegiatan ini adalah: 1) tidak ada limbah yang membahayakan bagi lingkungan sekitarnya, 2) tidak ada suara bising, 3) 
dapat dijadikan bahan sosialisasi terhadap pengusaha logam yang lain berkaitan dengan penggunaan teknologi produksi, 4) penghasilan pengusaha dan warga sekitar semakin meningkat, terutama dengan adanya tambahan tenaga kerja.

Seperti dijelaskan di atas bahwa permasalahan pokok pada pengrajin pande besi ini adalah pada teknologi proses produksi. Alat lama yang digunakan hanya menggunakan alat sederhana yaitu berupa batu gerinda yang diputar secara manual. Untuk mengatasi masalah yang berhubungan dengan teknologi tidak lain harus menggunakan teknologi tepat guna, yaitu dengan menggunakan mesin bubut serbaguna. Alat ini dapat bekerja untuk membentuk barang, menghalus atau meratakan, memotong dan kerja finishing. Permasalahan yang timbul adalah apakah dengan menggunakan alat yang ditawarkan pada program kegiatan vucer ini akan dapat meningkatkan produktivitas pengrajin pande besi dari sisi kuantitas dan kualitas?, Apakah dengan menggunakan alat baru ini pengrajin dan warga sekitarnya dapat meningkat kesejahteraannya?, Apakah dengan penggunaan teknologi baru ini pengrajin dapat memperoleh wawasan inovasi teknologi yang lebih efisien?, Apakah setelah menggunakan teknologi baru ini dapat merubah prilaku kearah yang lebih positif bagi pengrajin pande besi dalam hal menerapkan proses produksinya?.

\section{METODE}

Dalam pelaksanaan kegiatan ini metode yang dipakai adalah demonstrasi dan praktek langsung. Demonstrasi dilakukan pada tahap pengenalan alat kepada pengrajin logam, sedangkan praktek langsung dilakukan setelah sasaran ditengarai dapat menggunakan alat yang disiapkan untuk meningkatkan produksi.
Lokasi yang digunakan untuk melakukan kegiatan adalah di Desa Kalimati Tarik Sidoarjo di tempat Pengarajin Pande besi yang dipimpin oleh Bapak Ichan Ahmad.Pada bulan ke enam alat telah selesai diuji coba, dilanjutkan pada bulan ke tujuh, alat telah dioperasikan dan didemonstrasikan di depan pengrajin logam. Seterusnya pengrajin telah mampu mengoperasikan alat dengan baik.Kerangka pemecahan masalah yaitu dengan membuat alat/ mesin bubut serba guna system mekanik yang sesuai dengan kebutuhan pengrajin logam seperti jenis alat yang akan diproduksi. Dengan menggunakan alat/mesin bubut serba guna system mekanik, secara umum dapat meningkatkan mutu dan jumlah produk alat-alat pertanian, dan pertukangan. Alat ini telah teruji kemampuannya, yaitu dapat digunakan secara non-stop, serempak untuk beberapa pekerjaan bubut, pemotongan, dan finishing ujung logam.

Kecepatan kerja tinggi dalam waktu yang singkat sesuai dengan keinginan pengrajin dapat menyelesaikan pekerjaan, bahan besi yang diproduk menjadi lebih keras, tajam dan kokoh. Hasil bubutan kayu pemegang sabit, catok dan lainnya lebih halus dan artistic. Alat ini dapat dipergunakan secara nonstop, mudah mengoperasikannya, mudah dan murah merawatnya, mudah memperbaiki dan mudah mengganti komponen yang sekiranya rusak. Dengan alat ini bahan yang diproduksi seperti alat-alat pertanian dan pertukangan tidak mudah rusak. Keunggulan alat ini dapat bekerja secara cepat dan akurat. Dalam waktu 20 menit dapat menghasilkan empat buah sabit ataupun cangkul dan sejenisnya.

\section{HASIL DAN PEMBAHASAN}

Untuk mengetahui pencapaian tujuan pelaksanaan kegiatan, maka diadakan evaluasi yang diarahkan terhadap: (1) Efektivitas dan efisiensi 
teknologi alat/mesin bubut serba guna system mekanik dilihat dari besarnya pengeluaran biaya pembuatan dikaitkan dengan manfaat yang diperoleh dihitung dengan finansial. (2) Perubahan perilaku tenaga kerja sebelum dan sesudah menggunakan teknologi alat/mesin bubut serbaguna sistem mekanik. (3) Peningkatan pendapatan keluarga sebelum dan sesudah menggunakan teknologi.

Dari hasil penilaian diketahui bahwa kualitas produk dengan alat yang baru lebih baik dibandingkan dengan sebelum menggunakan alat yang baru tersebut. Dengan hasil tersebut menandakan bahwa dengan teknologi baru terjadi peningkatan kualitas dan kuantitas. Demikian pula terjadi efisiesi waktu kerja, yang tadinya proses produksi untuk satu buah alat pertanian atau pertukangan butuh waktu 18 menit untuk mengerjakan satu buah, sedang dengan alat baru cukup dengan waktu 5-8 menit. Dari sisi kemampuan dan ketangguhan, alat ini dapat dioperasikan secara nonstop dan biaya operasionalnya juga rendah. Yang tidak kalah penting adalah mutu hasil produk ditinjau dari sisi manapun akan lebih baik.

\section{KESIMPULAN}

Program vucer ini mempunyai manfaat yang besar terhadap pertumbuhan dan peningkatan pengrajin pande besi khususnya pengrajin pande besi yang dipimpin Bapak M. Ichsan Sholikin. Dari hasil evaluasi yang dilakukan, dapat disimpulkan bahwa: (1) Ada perbedaan yang signifikan dilihat dari hasil produksi alat-alat pertanian dan pertukangan baik dari sisi mutu dan jumlah, sebelum dan sesudah menggunakan alat tersebut. (2) Sebelum menggunakan alat mesin bubut serbaguna kualitas dan kuantitas produksi terbatas, sedang dengan alat yang baru kualitas dan kuantitas meningkat secara signifikan. (3) Terjadi efisiensi waktu, biaya, tenaga dan lainnya, setelah menggunakan alat yang baru.

\section{REFERENSI}

Bianchi, Bustraan. 1978. Pompa dan Kompresor. Pradnya Pramita. Jakarta.

Dtjen Dikti. 2006. Panduan Pengelolaan Hibah DP2M Dtjen Dikti Edisi VII Jakarta.

Harsono W, Toshie Okumura. 1981. Teknolgi Pengelasan Logam. Pradnya Paramita, Jakarta.

Tata Surdia, Shinroku Saito. 1985. Pengetahuan Bahan Teknik. Pradnya Paramita,Jakarta. 